\title{
Effects of Tetanus Toxin on Catecholamine Release from Intact and Digitonin-Permeabilized Chromaffin Cells
}

\author{
Mary A. Bittner and Ronald W. Holz \\ Department of Pharmacology, University of Michigan Medical School, Ann Arbor, Michigan, U.S.A.
}

\begin{abstract}
Tetanus exotoxin inhibited $\mathrm{Ca}^{2+}$-dependent catecholamine secretion in a dose-dependent manner in digitonin-permeabilized chromaffin cells. The inhibition was specific for tetanus exotoxin and the B fragment of tetanus toxin; the $\mathrm{C}$ fragment had no effect. Inhibition required the introduction of toxin into the cell, and was not seen when intact cells were preincubated with the toxin or toxin fragments. The degree of inhibition was related to the length of preincubation with toxin, as well as the concentration of toxin used. A short preincubation with toxin was sufficient to inhibit secretion, and the continued presence of toxin in the incubation medium was not required during the incubation with $\mathrm{Ca}^{2+}$. The inhibition of secretion by tetanus
\end{abstract}

toxin or the B fragment was not overcome with increasing $\mathrm{Ca}^{2+}$ concentrations. Tetanus toxin also inhibited catecholamine secretion enhanced by phorbol ester-induced activation of protein kinase $\mathrm{C}$. Thus, the toxin or a proteolytic fragment of the toxin can enter digitonin-permeabilized cells to interact with a component of the $\mathrm{Ca}^{2+}$-dependent exocytotic pathway to inhibit secretion. Key Words: Tetanus toxin-Chromaffin cell-Catecholamine-Exocytosis -Digitonin-permeabilized-Botulinum toxin. Bittner M. A. and Holz R. W. Effects of tetanus toxin on catecholamine release from intact and digitonin-permeabilized chromaffin cells. J. Neurochem. 51, 451-456 (1988).
Tetanus toxin inhibits secretion at central inhibitory synapses (Mellanby, 1984) and at the neuromuscular junction (Ambache et al., 1948; Kaeser and Saner, 1969; Mellanby and Thompson, 1972). Tetanus exotoxin is a 150 -kilodalton $(\mathrm{kDa})$ protein that consists of a heavy chain $(100 \mathrm{kDa})$ and a light chain $(50 \mathrm{kDa})$ held together by a disulfide bond. The toxin undergoes proteolytic cleavage by papain, resulting in a $45-\mathrm{kDa}$ fragment from the C-terminal of the heavy chain called the $C$ fragment. The remainder of the toxin molecule is termed the B fragment. Both fragments lack the toxicity of the intact toxin in vivo. The tissue binding site appears to be localized on the Cterminal of the heavy chain, since the $C$ fragment (1) shares binding sites with whole toxin in a number of preparations (Morris et al., 1980) and (2) antagonizes the action of exotoxin at the cholinergic neuromuscular junction (Simpson, 1985).

Although tetanus toxin inhibits the release of a number of neurotransmitters (Habermann and Dreyer, 1986), it has no effect on adrenergic neurons or on chromaffin cells (Knight et al., 1985). This lack of activity is a reflection of the inability of these cell types to bind and/or internalize the toxin. Recently, Neher and his colleagues (Penner et al., 1986) have demonstrated that tetanus toxin, when introduced into chromaffin cells via patch clamp pipet, was able to block $\mathrm{Ca}^{2+}$-dependent catecholamine secretion as measured by an increase in capacitance. The B fragment but not the $C$ fragment of tetanus toxin was also an effective inhibitor of exocytosis. The basis of the inhibition of secretion by either the intact toxin or the B fragment is unknown.

Incubation of chromaffin cells with low concentrations of the detergent digitonin renders the plasma membrane permeable to ions and to proteins without altering the integrity of the intracellular storage granules or of the secretory machinery (Dunn and Holz, 1983; Wilson and Kirshner, 1983; Holz and Senter, 1985 ). Secretion is directly stimulated by micromolar $\mathrm{Ca}^{2+}$ in the medium. In this study we have taken advantage of the permeability of digitonin-treated chromaffin cells to proteins to study the intracellular effects of tetanus toxin on $\mathrm{Ca}^{2+}$-dependent secretion.
Received November 30, 1987; accepted February 15, 1988.

Address correspondence and reprint requests to Dr. M. A. Bittner at M6322 Medical Science Building I, University of Michigan Medical School, Ann Arbor, MI 48109-0626, U.S.A.
Abbreviations used: BSA, bovine serum albumin; $\mathrm{kDa}$, kilodalton; KGEP, potassium glutamate, EGTA, PIPES-containing solution; PIPES, piperazine- $N, N$-bis(2-ethanesulfonic acid); PSS, physiological salt solution; TPA, 12-O-tetradecanoylphorbol acetate. 


\section{MATERIALS AND METHODS}

Primary dissociated cells from bovine adrenal medulla were prepared and maintained as monolayer cultures in Eagle's minimal essential medium (GIBCO, Grand Island, NY, U.S.A.) containing $10 \%$ heat-inactivated fetal calf serum. Cells were usually cultured as monolayers in 6.4$\mathrm{mm}$ diameter plastic culture wells (Costar, Cambridge, MA, U.S.A.) at a density of 500,000 cells $/ \mathrm{cm}^{2}$. For some experiments, suspended chromaffin cells were purified by differential plating, and then plated in collagen-coated plastic wells. Sterile calfskin collagen solution $\left(0.1 \mathrm{ml} / \mathrm{cm}^{2}\right.$, $50 \mathrm{~g} / \mathrm{ml}$ in $0.1 \%$ acetic acid) (Calbiochem, San Diego, CA, U.S.A.) was applied to each $6.4-\mathrm{mm}$ diameter well. Cells were prepared and plated in the presence of $1.3 \mu \mathrm{g} / \mathrm{ml} \mathrm{Fun-}$ gizone (Squibb, Princeton, NJ, U.S.A.). At least $12 \mathrm{~h}$ prior to the start of an experiment, the culture medium was replaced by medium without Fungizone. Experiments were performed 4-8 days after preparation of cultures.

Immediately before a secretion experiment, cells were incubated for $2 \mathrm{~h}$ in culture medium containing $\left[{ }^{3} \mathrm{H}\right]-$ norepinephrine and $0.5 \mathrm{~m} M$ ascorbate. Cultures were rinsed three times over $40 \mathrm{~min}$ with a physiological salt solution (CaPSS) containing $145 \mathrm{mM} \mathrm{NaCl}, 5.6 \mathrm{~m} M \mathrm{KCl}$, $2.2 \mathrm{~m} M \mathrm{CaCl}_{2}, 0.5 \mathrm{~m} M \mathrm{MgCl}_{2}, 5.6 \mathrm{~m} M$ glucose, $15 \mathrm{~m} M$ HEPES (pH 7.4), and $0.5 \mathrm{~m} M$ ascorbate. The potassium glutamate solution (KGEP solution) that was used for secretion experiments with digitonin contained $139 \mathrm{~m} M$ potassium glutamate, $20 \mathrm{~m} M$ piperazine- $N, N^{\prime}$-bis(2-ethanesulfonic acid) (PIPES) (pH 6.6), $2 \mathrm{mM} \mathrm{Mg} \mathrm{ATP,} 1 \mathrm{mM}$ $\mathrm{MgCl}_{2}, 5 \%$ bovine serum albumin (BSA), and either $5 \mathrm{mM}$ EGTA (without $\mathrm{Ca}^{2+}$ ) or $5 \mathrm{~m} M$ EGTA and various amounts of $\mathrm{CaCl}_{2}$ to yield buffered $\mathrm{Ca}^{2+}$ concentrations of $0-10 \mu M$. Toxin or toxin fragments were diluted from a stock containing $0.5 \mathrm{M} \mathrm{NaCl}$ and $0.1 \mathrm{M}$ phosphate buffer, pH 6.5. Control wells received an equal volume of $0.5 \mathrm{M}$ $\mathrm{NaCl}$ and $0.1 M$ phosphate buffer, $\mathrm{pH}$ 6.5. At the end of an experiment, the incubation solution was removed, and the
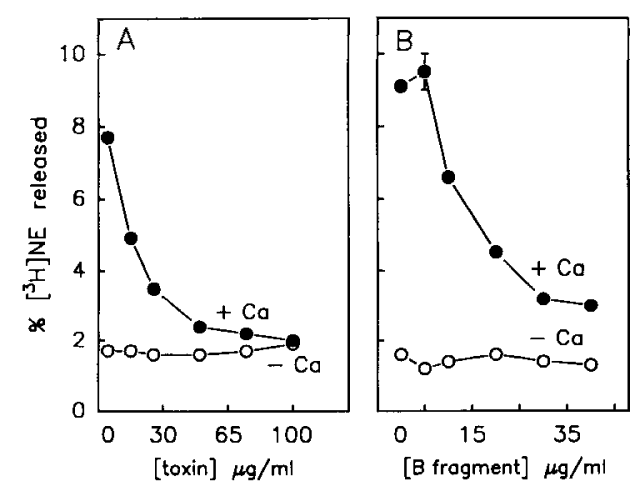

FIG. 1. Effect of tetanus exotoxin (A) or tetanus toxin $B$ fragment (B) on $\mathrm{Ca}^{2+}$-dependent secretion in digitonin-permeabilized chromaffin cells. Cells were permeabilized for $12 \mathrm{~min}$ in KGEP containing $20 \mu M$ digitonin, $1 \mathrm{mM} \mathrm{MgCl}, 2 \mathrm{mM} \mathrm{MgATP}, 5 \% \mathrm{BSA}$, and the indicated concentrations of toxin in the absence of $\mathrm{Ca}^{2+}$. The solution was replaced with KGEP with or without $10 \mu \mathrm{M} \mathrm{Ca}^{2+}$, and the cells were incubated for an additional $15 \mathrm{~min}$. In $\mathrm{A}$, tetanus exotoxin was present during the 12-min preincubation only; in $B$, tetanus toxin $B$ fragment was present throughout the second incubation as well. After $15 \mathrm{~min}$, the percentage of $\left[{ }^{3} \mathrm{H}\right]$ norepinephrine $\left(\left[{ }^{3} \mathrm{H}\right] \mathrm{NE}\right)$ released into the medium was determined. $n=3$ wells/group.

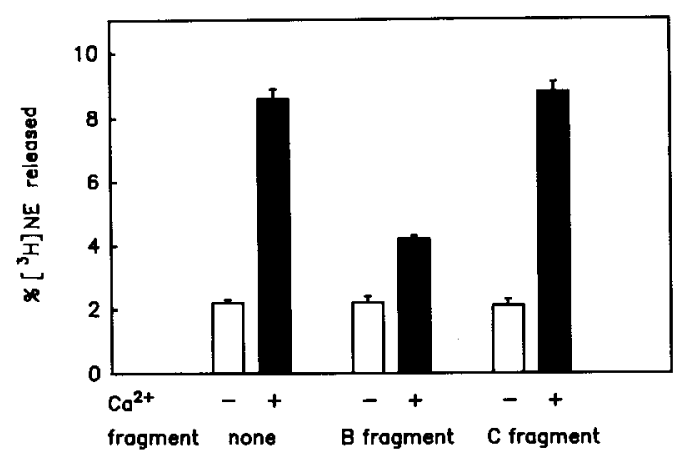

FIG. 2. Comparison of the effects of tetanus toxin $B$ and $C$ fragments on $\left[{ }^{3} \mathrm{H}\right]$ norepinephrine $\left(\left[{ }^{3} \mathrm{H}\right] \mathrm{NE}\right)$ secretion. Cells were permeabilized in KGEP containing $20 \mu M$ digitonin, $1 \mathrm{mM} \mathrm{MgCl}, 2$ $\mathrm{mM} \mathrm{MgATP}, 5 \% \mathrm{BSA}$, and $27.5 \mu \mathrm{g} / \mathrm{ml}$ of the toxin fragments or an equivalent volume of buffer for $10 \mathrm{~min}$ in the absence of $\mathrm{Ca}^{2+}$. This preincubation was removed, and the cells were incubated with or without $\mathrm{Ca}^{2+}$ in the continued presence of the toxin or buffer for $18 \mathrm{~min}$, and the amount of $\left[{ }^{3} \mathrm{H}\right]$ norepinephrine released was determined. $\mathbf{n}=3$ wells/group.

cells were lysed with $1 \%$ Triton X-100. The radioactivity released into the incubation solutions and the radioactivity remaining in the cells were determined by liquid scintillation spectrometry. Experiments were performed at $25^{\circ} \mathrm{C}$.

Data are expressed as means \pm SEM unless otherwise indicated. Significance between groups was determined by analysis of variance or by Student's $t$ test. Error bars smaller than symbols were omitted from figures.

Tetanus exotoxin $(2,000 \mathrm{Lf} / \mathrm{mg}$ protein) and tetanus toxin $\mathrm{B}$ and $\mathrm{C}$ fragments $(5,000 \mathrm{Lf} / \mathrm{mg}$ protein) were purchased from Calbiochem (San Diego, CA, U.S.A.), digitonin from Fluka Chemical (Hauppage, NY, U.S.A.), and $l-\left[{ }^{3} \mathrm{H}\right]$ norepinephrine $(21.4 \mathrm{Ci} / \mathrm{mmol})$ from New England Nuclear (Boston, MA, U.S.A.). Botulinum toxin and other reagents were obtained from Sigma Chemical (St. Louis, MO, U.S.A.).

\section{RESULTS}

Inhibition of catecholamine secretion by toxin

Tetanus toxin inhibited $\mathrm{Ca}^{2+}$-dependent secretion in digitonin-permeabilized chromaffin cells in a dose-related manner (Fig. 1). When cultured chromaffin cells were permeabilized in the presence of increasing concentrations of tetanus exotoxin (Fig. 1A), $\left[{ }^{3} \mathbf{H}\right]$ norepinephrine release was inhibited by $47 \%$ at $12.5 \mu \mathrm{g} / \mathrm{ml}$ and was virtually abolished at 100 $\mu \mathrm{g} / \mathrm{ml}$ exotoxin. Figure $1 \mathrm{~B}$ demonstrates that the inhibitory effects of the B fragment of tetanus toxin were similar to those of intact exotoxin.

The inhibition of $\mathrm{Ca}^{2+}$-dependent secretion was due to a specific effect of the active exotoxin or B fragment, since it did not occur in cells treated with the inactive $\mathrm{C}$ fragment of the toxin (Fig. 2). Treatment with $27.5 \mu \mathrm{g} / \mathrm{ml}$ of toxin B fragment inhibited secretion by $69 \%$, whereas the same concentration of $C$ fragment had no effect.

Role of permeabilization in permitting toxin actions

In contrast to the marked inhibition of secretion seen when permeabilized cells were preincubated 
with either exotoxin or B fragment, little or no effect on secretion was seen when intact cells were incubated with the toxins. Preincubation of nonpermeabilized cells for $15 \mathrm{~min}$ with $125 \mu \mathrm{g} / \mathrm{ml}$ exotoxin or 50 $\mu \mathrm{g} / \mathrm{ml} \mathrm{B}$ fragment had no effect on secretion stimulated by the nicotinic agonist dimethylphenylpiperazinium, $2.2 \mathrm{mM} \mathrm{Ba}{ }^{2+}$, or elevated $\mathrm{K}^{+}$(data not shown). When intact cells were incubated with 80 $\mu \mathrm{g} / \mathrm{ml}$ of B fragment or $125 \mu \mathrm{g} / \mathrm{ml}$ exotoxin for 15 min, secretion induced by $10 \mu M \mathrm{Ca}^{2+}$ from subsequently permeabilized cells was also unaltered. When chromaffin cells were treated with either $30 \mu \mathrm{g} / \mathrm{ml} \mathrm{B}$ fragment or 25 or $75 \mu \mathrm{g} / \mathrm{ml}$ exotoxin in culture medium for up to $45 \mathrm{~h}$ and subsequently stimulated with dimethylphenylpiperazinium or $2.2 \mathrm{mM} \mathrm{Ba}^{2+}$, or de-

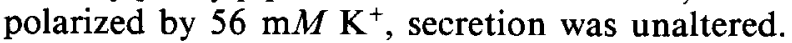
Similarly, when chromaffin cells were incubated with the same concentrations of the toxins for 22 or $45 \mathrm{~h}$, secretion induced by $10 \mu M \mathrm{Ca}^{2+}$ in subsequently permeabilized cells was no different from that of vehicle-treated cells. The data demonstrate that both the exotoxin and tetanus toxin B fragment must gain access to the cell interior to inhibit catecholamine release.

The effect of preincubating permeabilized cells with increasing amounts of tetanus toxin $B$ fragment for various times is shown in Fig. 3. $\mathrm{Ca}^{2+}$-dependent secretion in the absence of toxin decreased with increasing length of permeabilization (Dunn and Holz, 1983). For any given toxin concentration, increasing the period of exposure to toxin increased the degree of inhibition seen. Thus, addition of toxin B fragment $(30-80 \mu \mathrm{g} / \mathrm{ml})$ simultaneously with $\mathrm{Ca}^{2+}$ had no effect on secretion (data not shown). If cells were preincubated for $6 \mathrm{~min}$ with $20 \mu \mathrm{g} / \mathrm{ml}$ toxin, the inhibition was $24 \%$, whereas increasing the preincubation time to 12 min gave a $54 \%$ inhibition. Similarly, in-

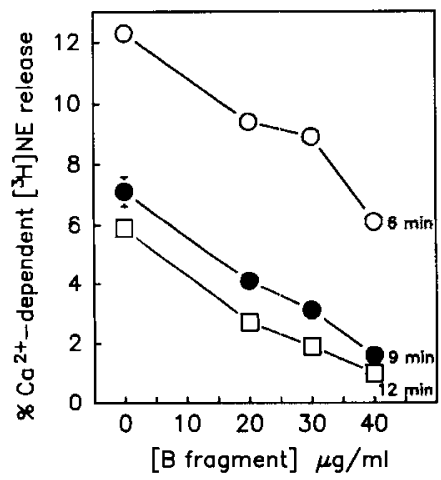

FIG. 3. Time course of preincubation with tetanus toxin B fragment. Cells were permeabilized in KGEP containing $20 \mu M$ digitonin, $1 \mathrm{mM} \mathrm{MgCl}, 2 \mathrm{mM} \mathrm{MgATP}, 5 \% \mathrm{BSA}$, and the indicated concentration of tetanus toxin B fragment or buffer for 6,9 , or 12 $\mathrm{min}$. After the removal of the preincubation, cells were incubated in KGEP for 15 min without toxin in the presence or absence of 10 $\mu M \mathrm{Ca}^{2+} . n=3$ wells/group. $\left[{ }^{3} \mathrm{H}\right] \mathrm{NE},\left[{ }^{3} \mathrm{H}\right]$ norepinephrine.
TABLE 1. Effects of various preincubation times on the ability of tetanus toxin $B$ fragment to inhibit secretion

\begin{tabular}{|c|c|c|c|}
\hline \multirow[b]{2}{*}{ Group } & \multicolumn{2}{|c|}{ Preincubations } & \multirow{2}{*}{$\begin{array}{c}\mathrm{Ca}^{2+} \text {-dependent } \\
{\left[{ }^{3} \mathrm{H}\right] \text { norepinephrine }} \\
\text { secretion }\end{array}$} \\
\hline & 1 & 2 & \\
\hline 1 & - & - & $10.5 \pm 0.4$ \\
\hline 2 & - & + & $8.2 \pm 0.4^{a}$ \\
\hline 3 & + & - & $5.3 \pm 0.4^{b}$ \\
\hline 4 & + & + & $4.9 \pm 0.4^{b}$ \\
\hline
\end{tabular}

Cells were permeabilized for $3 \mathrm{~min}$ in KGEP solution containing $20 \mu M$ digitonin and $5 \mathrm{mg} / \mathrm{ml} \mathrm{BSA}$. Cells were then preincubated for $3 \mathrm{~min}$ with (+) or without $(-) 50 \mu \mathrm{g} / \mathrm{ml}$ tetanus toxin B fragment in KGEP containing BSA. The solution was removed, and cells preincubated for an additional $3 \mathrm{~min}$ with or without $\mathrm{B}$ fragment $(50 \mu \mathrm{g} / \mathrm{ml})$ in KGEP with BSA. Again, solutions were removed and cells were incubated for $15 \mathrm{~min}$ in KGEP in the presence or absence of $10 \mu M \mathrm{Ca}^{2+} . \mathrm{n}=3$ wells/group. A two-factor (treatment by $\mathrm{Ca}^{2+}$ level) analysis of variance was completed. This was followed by multiple comparisons for the differences in means by treatments with $\mathrm{Ca}^{2+}$ present versus $\mathrm{Ca}^{2+}$ absent by the Bonferroni method (Neter and Wasserman, 1974).

${ }^{a} \mathrm{p}<0.01$ compared with Groups 1,3 , and 4 .

${ }^{b} \mathrm{p}<0.01$ compared with Groups 1 and 2.

creasing the concentration of toxin permitted a higher degree of inhibition after a shorter preincubation. A $50 \%$ inhibition of secretion resulted from a 12 -min preincubation with $20 \mu \mathrm{g} / \mathrm{ml}$ toxin or a 6-min preincubation with $40 \mu \mathrm{g} / \mathrm{ml}$.

The data demonstrated that a preincubation with toxin was necessary for inhibition of secretion, but it was unclear whether this was simply a reflection of the time required for the toxin to enter the cell, or whether the toxin might require some time to exert its effects. The experiment shown in Table 1 was designed to distinguish between these possibilities. A 3-min preincubation of permeabilized cells in the absence of toxin followed by a 3-min preincubation with tetanus toxin $B$ fragment immediately prior to incubation with $\mathrm{Ca}^{2+}$ caused a slight $(21 \%)$ inhibition of secretion, whereas a 3-min preincubation with B fragment followed by an additional 3-min preincubation in the absence of toxin inhibited $\mathrm{Ca}^{2+}$-dependent secretion by $50 \%$. There was no difference between this latter group and cells that were exposed to toxin during both 3-min preincubations. Thus, although time is undoubtedly necessary for toxin to enter the cell, it is clear that additional time is required for the toxin to exert its effects.

\section{Time course of secretion}

After a $12-$ min permeabilization with $30 \mu \mathrm{g} / \mathrm{ml} \mathrm{B}$ fragment, there was between 71 and $74 \%$ inhibition at all times measured (3-21 min) (Fig. 4). $\mathrm{Ca}^{2+}$-dependent secretion was virtually complete by $9 \mathrm{~min}$ in both control and toxin-treated cells. Hence, the extent but not the time course of secretion was altered by the toxin. 


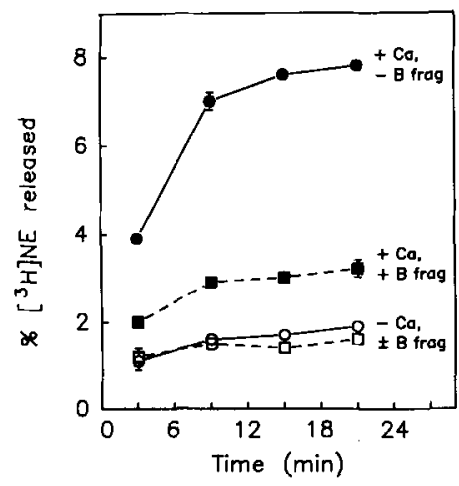

FIG. 4. Effect of preincubation with tetanus toxin on the time course of $\mathrm{Ca}^{2+}$-dependent secretion. Cells were permeabilized for $12 \mathrm{~min}$ in KGEP containing $20 \mu \mathrm{M}$ digitonin, $1 \mathrm{mM} \mathrm{MgCl}, 2 \mathrm{mM}$ MgATP, $5 \% \mathrm{BSA}$, and $30 \mu \mathrm{g} / \mathrm{ml}$ tetanus toxin B fragment or the appropriate amount of buffer. Cells were then incubated without toxin for $3,9,15$, or $21 \mathrm{~min}$ in the presence or absence of $10 \mu \mathrm{M}$ $\mathrm{Ca}^{2+}$, and the amount of $\left[{ }^{3} \mathrm{H}\right]$ norepinephrine $\left(\left[{ }^{3} \mathrm{H}\right] \mathrm{NE}\right)$ released was determined. $n=3$ wells/group.

\section{$\mathrm{Ca}^{2+}$ dose-response curve and $\mathrm{pH}$ effects}

Increasing the $\mathrm{Ca}^{2+}$ concentration was not able to overcome the inhibition of secretion induced by tetanus toxin B fragment $(40 \mu \mathrm{g} / \mathrm{ml})$ (Fig. 5) or by tetanus exotoxin $(125 \mu \mathrm{g} / \mathrm{ml})$ (data not shown). Thus, the major effect of the toxin is to inhibit the maximal extent of secretion rather than the sensitivity of the secretory pathway to $\mathrm{Ca}^{2+}$.

The preceding experiments were all performed using KGEP buffer at $\mathrm{pH}$ 6.6. Secretion induced by 1 $\mu M \mathrm{Ca}^{2+}$ was inhibited identically at pH 6.6 and $\mathrm{pH}$ 7.0 (data not shown).

\section{Effect of toxin on the enhancement of secretion by phorbol esters}

In chromaffin cells, incubation of intact cells with the phorbol ester 12-O-tetradecanoylphorbol-13-acetate (TPA) activates protein kinase $C$ and markedly enhances the secretory response to micromolar $\mathrm{Ca}^{2+}$ in subsequently permeabilized cells (Pocotte et al., 1985; Lee and Holz, 1986; TerBush and Holz, 1986).

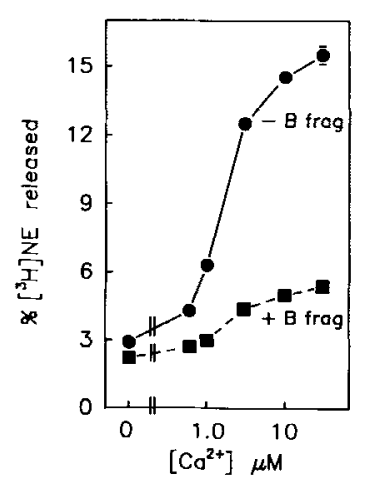

FIG. 5. Effect of preincubation with tetanus toxin $B$ fragment on the $\mathrm{Ca}^{2+}$ dose-response curve for secretion. Cells were permeabilized for $6 \mathrm{~min}$ in KGEP containing $20 \mu \mathrm{M}$ digitonin, $1 \mathrm{mM}$ $\mathrm{MgCl}_{2}, 2 \mathrm{mM}$ MgATP, 5\% BSA, and $40 \mu \mathrm{g} / \mathrm{ml}$ tetanus toxin $B$ fragment or an equivalent amount of buffer. After removal of the preincubation, cells were incubated for $15 \mathrm{~min}$ with the indicated $\mathrm{Ca}^{2+}$ concentrations in the absence of toxin, and the amount of $\left[{ }^{3} \mathrm{H}\right]$ norepinephrine $\left(\left[{ }^{3} \mathrm{H}\right] \mathrm{NE}\right)$ released was determined. $n=3$ wells/group.

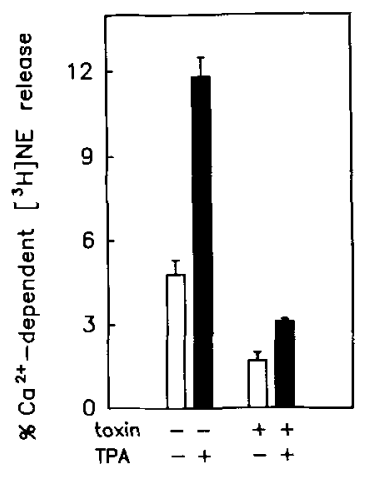

FIG. 6. Effect of preincubation with tetanus exotoxin on the phorbol ester-induced enhancement of secretion. Cells were incubated for $30 \mathrm{~min}$ in CaPSS containing $100 \mathrm{nM}$ TPA or CaPSS only. Cells were permeabilized in KGEP with $20 \mu M$ digitonin in the presence or absence of $100 \mathrm{nM}$ TPA and with or without $125 \mu \mathrm{g} / \mathrm{ml}$ tetanus exotoxin for 6 min. Cells were then incubated with or without $1 \mu M \mathrm{Ca}^{2+}$. in the absence of TPA or exotoxin, for $15 \mathrm{~min}$, and the amount of $\left[{ }^{3} \mathrm{H}\right]$ norepinephrine $\left(\left[{ }^{3} \mathrm{H}\right] \mathrm{NE}\right)$ released was determined. $n=3$ wells/group.

When cells that had been preincubated with $100 \mathrm{n} M$ TPA were permeabilized in the presence of $125 \mu \mathrm{g} / \mathrm{ml}$ tetanus exotoxin, the enhancement of secretion due to TPA was also inhibited (Fig. 6). Thus, it is possible that the toxin inhibits at a common site both the $\mathrm{Ca}^{2+}$-dependent secretion that occurs in the absence of TPA-induced activation of protein kinase $C$ and $\mathrm{Ca}^{2+}$-dependent secretion enhanced by TPA-induced activation of protein kinase $\mathrm{C}$.

\section{Effect of botulinum A toxin}

Preincubation of intact chromaffin cells with 1 $\mu \mathrm{g} / \mathrm{ml}$ botulinum A toxin for $45 \mathrm{~h}$ had no effect on secretion stimulated by dimethylphenylpiperazin-

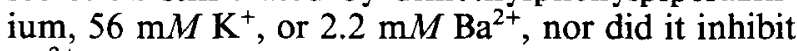
$\mathrm{Ca}^{2+}$-dependent secretion from subsequently permeabilized cells (data not shown). In a single experiment, chromaffin cells were permeabilized for 12 min in the presence of $20 \mu \mathrm{g} / \mathrm{ml}$ botulinum A toxin, and were stimulated to secrete by $10 \mu M \mathrm{Ca}^{2+}$ in the absence of the toxin. In this experiment, botulinum A toxin inhibited $\mathrm{Ca}^{2+}$-dependent $\left[{ }^{3} \mathrm{H}\right]$ norepinephrine release by $68 \%$.

\section{DISCUSSION}

Although the toxic properties of the clostridial neurotoxins have been studied for almost a century, relatively little is known about the specific mechanisms whereby these toxins exert their effects. By analogy with other toxins that are better characterized, a three-step model has been proposed (Schmitt et al., 1981; Simpson, 1986). The first step is binding to the cell membrane, followed by internalization of the toxin, and finally interaction of the possibly modified toxin with some intracellular target molecule. The identity of this putative target is at present unknown.

Preincubation of intact chromaffin cells with tetanus toxin had no effect on nicotinic agonist-, elevated $\mathrm{K}^{+}$, or $\mathrm{Ba}^{2+}$-induced secretion from intact cells or on secretion induced by micromolar concentrations of $\mathrm{Ca}^{2+}$ in subsequently permeabilized cells. However, when cells were first permeabilized with digitonin to 
bypass the binding and internalization steps, tetanus toxin was indeed an effective inhibitor of $\mathrm{Ca}^{2+}$-dependent secretion. The inhibition required time to develop, was dependent on the concentration of toxin, and occurred at physiological concentrations of $\mathrm{Ca}^{2+}(0.1-30 \mu M)$. Our work confirms the results of Neher and his colleagues who used patch clamp techniques (Penner et al., 1986) to demonstrate that secretion in chromaffin cells can be inhibited by tetanus toxin (or botulinum A toxin) if it gains access to the cell interior. We also confirm that the active portion of the tetanus toxin molecule is the $\mathrm{B}$ rather than the $\mathrm{C}$ fragment.

The effects of tetanus toxin have been studied at the cholinergic neuromuscular junction. At the rat soleus neuromuscular junction, blockade of stimulated acetylcholine release by tetanus toxin could be partially overcome by manipulations that raised the intracellular $\mathrm{Ca}^{2+}$ (Bevan and Wendon, 1984). The authors suggested that the maximum number of quanta releasable by nerve stimulation was reduced. These data are consistent with the effects of tetanus toxin in chromaffin cells. We found that the maximal secretory response elicited by $\mathrm{Ca}^{2+}$ was reduced. The more direct analysis possible in the permeabilized chromaffin cells demonstrated that the fractional inhibition due to toxin was virtually identical over a wide range of $\mathrm{Ca}^{2+}$ concentrations (Fig. 5).

The effects of botulinum $D$ toxin are similar to those of tetanus toxin observed in our experiments. When cultured chromaffin cells were preincubated for $48 \mathrm{~h}$ with $50 \mu \mathrm{g} / \mathrm{ml}$ botulinum D toxin, and subsequently rendered permeable by brief exposure to intense electric fields, $\mathrm{Ca}^{2+}$-dependent catecholamine release was virtually abolished (Knight, 1987). Pretreatment of intact cells with lower concentrations of botulinum D toxin $(5 \mu \mathrm{g} / \mathrm{ml})$ for $48 \mathrm{~h}$ before electrical permeabilization resulted in a partial inhibition of secretion that could not be overcome by $\mathrm{Ca}^{2+}$.

Dreyer and Schmitt (1983) measured the amplitude distribution of miniature end-plate potentials in the mouse hemidiaphragm both before and after tetanus toxin treatment, and showed that the toxin inhibited normal amplitude potentials without inhibiting smaller amplitude potentials. They suggest that in the motor neuron there may be either two mechanisms for the spontaneous release of secretory vesicles or two categories of vesicles, only one of which is susceptible to inhibition by tetanus toxin. However, Bevan and Wendon (1984) observed that tetanus toxin had little or no effect on either the frequency or the amplitude of spontaneous miniature end-plate potentials in the rat soleus preparation. When permeabilized chromaffin cells were preincubated with tetanus toxin B fragment for $12 \mathrm{~min}$ before the addition of $\mathrm{Ca}^{2+}$, secretion was inhibited to the same extent throughout the entire time course of the experiment (Fig. 4). Furthermore, a sufficiently high concentration of toxin totally abolished $\mathrm{Ca}^{2+}$-dependent secre- tion (Fig. 1A). Thus, there is neither a temporally distinguishable mechanism of secretion nor a special pool of granules that is sensitive to the toxin.

Incubation of permeabilized chromaffin cells with toxin inhibited secretion subsequently induced by micromolar $\mathrm{Ca}^{2+}$ in the absence of toxin. The degree of inhibition increased with the length of incubation with toxin (Fig. 3). One possible cause of the timedependent inhibition is the time required for toxin entry into the permeabilized cell. The enzyme lactate dehydrogenase exits the digitonin-permeabilized cell with a half-life of 10-15 min (Dunn and Holz, 1983). Since the molecular weights of tetanus exotoxin (150 $\mathrm{kDa}$ ) and the $\mathrm{B}$ fragment ( $95 \mathrm{kDa}$ ) are similar to that of lactate dehydrogenase (134 kDa), one might expect the kinetics of their entry into the cell to be similar. Experiments in vivo and in cell culture (Bergey et al., 1983) have demonstrated a latency period before tetanus toxin exhibits its activity. Because of the relatively long times involved for binding and internalization, it is uncertain whether the inhibitory effect of the toxin requires time to develop once toxin has entered the cell. In the present experiments, there is a time-dependent step after toxin entry which is necessary for inhibition, since pretreatment with toxin immediately prior to the addition of $\mathrm{Ca}^{2+}$ was relatively ineffective, whereas an identical toxin treatment followed by an additional 3-min preincubation before the addition of $\mathrm{Ca}^{2+}$ resulted in a $50 \%$ inhibition (Table 1).

The data indicate that the toxin interacts with a component of the secretory pathway before the introduction of $\mathrm{Ca}^{2+}$. It has been suggested that tetanus toxin may enzymatically modify a target involved in exocytosis, analogous to the ADP-ribosylating activity of cholera, pertussis, or diphtheria toxins. While such an enzymatic mechanism of action might be expected to result in a long-lived effect, to date no enzymatic activities have been associated with the tetanus toxin molecule.

In summary, we have shown that inhibition of secretion by tetanus toxin or its B fragment requires time to develop and is not overcome by increasing the $\mathrm{Ca}^{2+}$ concentration. The target of the toxin appears to be a necessary component of the $\mathrm{Ca}^{2+}$-dependent exocytotic pathway. Thus, digitonin-permeabilized chromaffin cells are a useful model in which to study the biochemical basis for the action of tetanus toxin. Furthermore, the identification of the target of tetanus toxin in chromaffin cells may advance our understanding of the process of exocytosis.

Acknowledgment: We would like to thank Dr. Michael A. Schork (University of Michigan School of Public Health) for help with the statistical analysis of the data. The work was supported by PHS grant R01 DK27959.

\section{REFERENCES}

Ambache N., Morgan R. S., and Wright G. P. (1948) The action of tetanus toxin on the rabbit's iris. J. Physiol. (Lond.) 107, 45-53. 
Bergey G. K., Macdonald R. L., Habig W. H., Hardegree M. C., and Nelson P. G. (1983) Tetanus toxin: convulsant action on mouse spinal cord neurons in culture. J. Neurosci. 3, $2310-2323$.

Bevan S. and Wendon L. M. B. (1984) A study of the action of tetanus toxin at rat soleus neuromuscular junctions. J. Physiol. (Lond.) 348, 1-17.

Dreyer F. and Schmitt A. (1983) Transmitter release in tetanus and botulinum A toxin-poisoned mammalian motor end-plates and its dependence on nerve stimulation and temperature. Pflugers Arch. 399, 228-234.

Dunn L. A. and Holz R. W. (1983) Catecholamine secretion from digitonin-treated adrenal medullary chromaffin cells. J. Biol. Chem. 258, 4989-4993.

Habermann E. and Dreyer F. (1986) Clostridial neurotoxins: handling and action at the cellular and molecular level. Curr. Top. Microbiol. Immunol. 129, 93-179.

Holz R. W. and Senter R. A. (1985) Plasma membrane and chromaffin granule characteristics in digitonin-treated chromaffin cells. J. Neurochem. 45, 1548-1557.

Kaeser H. E. and Saner A. (1969) Tetanus toxin, a neuromuscular blocking agent. Nature 223, 842.

Knight D. E. (1987) Calcium and diacylglycerol control of secretion. Biosci. Rep. 7, 355-367.

Knight D. E., Tonge D. A., and Baker P. F. (1985) Inhibition of exocytosis in bovine adrenal medullary cells by botulinum toxin type D. Nature 317, 719-721.

Lee S. A. and Holz R. W. (1986) Protein phosphorylation and secretion in digitonin-permeabilized adrenal chromaffin cells: effects of micromolar $\mathrm{Ca}^{2+}$, phorbol esters and diacylglycerol. J. Biol. Chem. 261, 17089-17098.

Mellanby J. (1984) Comparative activities of tetanus and botulinum toxins. Neuroscience 11, 29-34.

Mellanby J. and Thompson P. A. (1972) The effect of tetanus toxin at the neuromuscular junction in the goldfish. $J$. Physiol. (Lond.) 224, 407-419.

Morris N. P., Consiglio E., Kohn L. D., Habig W. H., Hardegree M. C., and Helting T. B. (1980) Interaction of fragments B and $C$ of tetanus toxin with neural and thyroid membranes and with gangliosides. J. Biol. Chem. 255, 6071-6076.

Neter J. and Wasserman W. (1974) Applied Linear Statistical Models Regression, Analysis of Variance and Experimental Design, p. 480. Richard D. Irwin, Homewood, Illinois.

Penner R., Neher E., and Dreyer F. (1986) Intracellularly injected tetanus toxin inhibits exocytosis in bovine adrenal chromaffin cells. Nature 324, 76-78.

Pocotte S. L., Frye R. A., Senter R. A., TerBush D. R., Lee S. A., and Holz R. W. (1985) Effects of phorbol ester on catecholamine secretion and protein phosphorylation in adrenal medullary cell cultures. Proc. Natl. Acad. Sci. USA 82, 930-934.

Schmitt A., Dreyer F., and John C. (1981) At least three sequential steps are involved in the tetanus toxin-induced block of neuromuscular transmission. Naunyn Schmiedebergs Arch. Pharmacol. 317, 326-330.

Simpson L. L. (1985) Pharmacological experiments on the binding and internalization of the 50,000 dalton carboxyterminus of tetanus toxin at the cholinergic neuromuscular junction. $J$. Pharmacol. Exp. Ther. 234, 100-105.

Simpson L. L. (1986) Molecular pharmacology of botulinum toxin and tetanus toxin. Annu. Rev. Pharmacol. Toxicol. 26, 427-453.

TerBush D. R. and Holz R. W. (1986) Effects of phorbol esters, diglyceride, and cholinergic agonists on the subcellular distribution of protein kinase $\mathrm{C}$ in intact or digitonin-permeabilized adrenal chromaffin cells. J. Biol. Chem. 261, 17099-17106.

Wilson S. P. and Kirshner N. (1983) Calcium-evoked secretion from digitonin-permeabilized adrenal medullary chromaffin cells. J. Biol. Chem. 258, 4994-5000. 